\title{
PROTECTION FROM MISLEADING ADVERTISEMENT UNDER THE JORDAN CIVIL LAW 1976 AND THE DRAFT LAW OF CONSUMER PROTECTION 2013
}

\author{
AHMAD IBRAHIM AL SHARU*1 \\ FAUZIAH BINTI MOHD NOOR ${ }^{2}$ \\ ROHANA BINTI ABDUL RAHMAN ${ }^{3}$ \\ ${ }^{* 1,2,3}$ School of law, Universiti Utara Malaysia, Malaysia \\ * (ahmadshr85@yahoo.com)
}

This journal is licensed under a Creative Commons Attribution-NonCommercial 4.0 International License (CC-BY-NC). Articles can be read and shared for noncommercial purposes under the following conditions:

- BY: Attribution must be given to the original source (Attribution)

- NC: Works may not be used for commercial purposes (Noncommercial)

This license lets others remix, tweak, and build upon your work non-commercially, and although their new works must also acknowledge you and be non-commercial, they don't have to license their derivative works on the same terms. License Deed Link: http://creativecommons.org/licenses/by-nc/4.0/ Legal Code Link: http://creativecommons.org/licenses/by-nc/4.0/legalcode $A B C$ Research Alert uses the CC BY-NC to protect the author's work from misuse.

\begin{abstract}
Commercial advertisements play a crucial role in identifying features and specifications of goods and products. However, misleading advertising has become one of main forms unfair practise customers/ consumers. Jordan considered as one of the countries that does not have rules and provisions that regulate the consumer protection specifically misleading advertisements. This paper discussed about the Jordanian laws in protecting the consumer from misleading advertisements. The objective of the article to examine how the Jordanian provisions by the Civil law 1976 and the Jordanian Draft law of Consumer Protection 2013 protect consumers from misleading advertisements in Jordan. This paper has examined the subject of consumer protection in misleading advertisement and the provisions available in Jordan as protection to consumers from misleading advertisements. In order to achieve this purpose, the existing rules and laws, facts, principles, concepts and the law provisions has been examined and analyzed.
\end{abstract}

Keywords

Consumer protection, misleading advertisements, Jordan civil Law 1976, Draft Law 2013.

\section{INTRODUCTION}

There is no doubt that the commercial advertisements play a key role in informing a consumer the nature of the goods and how it could benefit consumers. Commercial advertisement contains specific and express information in this regard which affects customers' satisfaction and directs his/her choice of a certain product or service. However, in certain circumstances, the information provided in the advertisement is not hundred percent true as it is and sometimes the advertisement consists of misleading information that could lead to deception and fraud. Many countries around the world has promulgated consumer law and set out specific provisions of misleading advertisements to protect consumers. For instance, Consumer Protection law in UK (1987), the Australian Consumer Law (2001), the Malaysian Consumer Protection Act 
(CPA1999), Syrian Consumer Protection law 2015 and United Arab Emirate Law 2006 of Consumer Protection.

In present, Jordan does not have a specific legislation on consumer protection specifically misleading advertisements. However, Jordan has proposed the Draft Law 2013 of Consumer Protection in the Parliament, but until today the law has not been passed yet. The absence of a legal framework for consumer protection in the Jordan is an issue to be addressed by Jordanian government. The available legal provisions deal with fraud in sale and trade, and they must be modified to fit the case of commercial. Though the level of integration between sale and advertising is high since they depend on tools of persuasion and influence, the commercial is different since it is a promotional activity carried out through Multi-media, such as television, radio, newspapers and Internet (Naji \& Mula, 2000).

Consumers of Jordanian believed that advertiser and seller is not provide proper information and that information is not sufficient for decision making and if there is any issue, enquires and problem, there would be a difficult to find the contact details in solving all issues and enquires. Moreover, if seller gives the consumers' incomplete and insufficient information related to the product and also their identity, perception of consumers is that they would not be effectively protected. Hence, Jordanian Government is essential and necessary to control and check misleading, deceptive, immoral and highly competitive advertising.

\section{PROTECTION FROM MISLEADING ADVERTISEMENT UNDER THE CIVIL LAW 1976 (JCL)}

In Jordan, the Jordan Civil Law (JCL) 1976, is the main law for all private laws in Jordan and is thus considered to be the applicable law in the absence of any rules (Alsarhan, A, 2005). The JCL 1976 has provided several important elements in its provision. This paper will identify the general provisions established in the JCL and look for the rules that may be adopted by a consumer to provide the legal protection from the misleading advertising whether in the general theory of the contract or in the rules of tort. It will also discuss the sufficiency of the general rules in the JCL in providing consumer protection, or special rules that should be developed to fulfill the required level to protect the consumer from misleading advertisements.

The JCL does not define misleading but adopted the deception under this law. The deception could lead to a mistaken consent, the rules on mistake are argued as an appropriate substitute for those governing deception (Abd El-Razzak El Sanhuri, 1960). The definition of deception by the Jordanian Civil Law 1976 will be discussed further in this paper.

\section{DECEPTION WITH FRAUD AND FALSE ADVERTISEMENT IN JCL 1976}

Deception with fraud is considered a satisfaction defect in the Jordan Civil Law. Article (143) of the said law defines "deception" as follows: "either party deceives the other party using action or verbal fraudulent means to drive the latter to feel satisfied with what he would not have satisfied if such means does not exist" (Jordan Civil Law, s 143).

In addition, article (143) provides that it is required to prove deception that either party uses fraudulent means that convince the other party to enter into the contract, whether verbal or nonverbal means. In applying this to the commercials, is lying or misleading contained in the commercial considered deception that makes defect in satisfaction? The Jordan Law does not clarify whether lying is considered deception or not, and there are no court decisions examining 
the adaption of considering lying as deception (Khasawneh, Maha Youssef, and Hattab, Rasha Mohammed Tayseer, 2012).

Moreover under the provisions of the JCL, deception alone is not considered a satisfaction defect, rather it should be associated with fraud, where Article (145) of the said Law provides that "If either party deludes the other party and the latter discovers that the contract has been made upon fraud, then the latter may terminate the contract" ( Jordan Civil Law.s 145). It should be noted that not each case of lying is considered deception that finds fault with satisfaction. The over-praise and promotion of a product by a producer might don't reach to the level of deception, where advertising or promotion may be included in the so-called acceptable or permissible deception according to customs and traditions (Sarhan and Nouri, 2009).

Whether deception affects execution of the contract or not is left at discretion of the trial judge who should measure it based on an objective criterion, where the judge does not consider the consumer himself but the normal person (Khasawneh and Hattab, 2012). Notwithstanding the foregoing, proving deception with fraud evokes some difficulties, where a consumer is obliged to prove that the deception is the motive of contracting, where he should not have entered into a contract, or entered into a contract under different contractual conditions, if there has been no deception (Wahdan, Reda Metwali, 2008).

Jorden marketplace, in the situation where disputes and difference arise, traditional way is only one available way for consumers to access redress. This happens due to the absence and lack of regulation that protect the issues of consumers, especially with related to the internet. The traditional route is exemplified in the ordinary civil litigation mechanism for compensating parties inversely affected by wrongful and unlawful conduct. The traditional mechanism can be explained as complex, expensive and slow which does not encourage the protection of consumers particularly related to the consumer's small amount of compensation that is available and present for the consumers (Alhusban, Ahmad, 2014).

The JCL is not related to the intention and conduct of the defendant but will be fine the defendant liable, if her/his omission and commission constitutes negligence and intentional harm (Abdelaziz Lasasmeh, 2006).

\section{THE RIGHT OF WITHDRAWAL FOR CONSUMER UNDER THE JCL 1976}

An offer can be identified as a definite expression issued by a party to the other party with the aim of concluding a contract (Jordan Civil Law, 1976). The offer presented by a person must be clear and definite where if it is associated with acceptance of the other party the contract is entered into. Otherwise, an offer will be a call for negotiation, and then no obligations upon advertiser will be imposed (Sarhan and Khater, 2005). As to the position of the Jordan Civil Law, Para (2) of Article (94) provides that the publication, advertisement, applicable price list and any other statement in connection with offers or demands addressed to the public or individuals shall not, when doubtful, be an offer but a call for negotiation (Jordan Civil Law, 1976).

Legislation of Jordanian does not recognize the right for the consumer's withdrawals. In any situation, once a valid contract produced or acceptance has been given, consumers have no right to cancel and withdraw their contract for the services and good (Alhusban, Ahmad, 2014). Consequently, according to the rules of JCL, if the contract is binding and valid, it shall not be allow for the contracting parties to change decisions unilaterally and individually, nor to differ 
and withdraw the contract, expect by the both parties common consent, under the law provision, or the law and order of court. By this rule, it is clear that both parties have clear restrictions right to modified and terminate the contract excluding by the routes mentioned above.

According to legislation of Jordanian and JCL, provides no right for the cancelation of contract; rather, the contracting parties shall be cancel or withdraw the contract due to some circumstances.(i-e, deception, misrepresentation, option of conditionality, mistake, opinion of inspection, opinion of defects and also in the case of opening of contract, mostly in the case of non-performance) (Civil Law of Jordan. s 145). Moreover, the above principles provides a clear information that contracts cannot be withdraw their contract, or modified expect by the mutual understanding regarding withdrawal of contract (agreement) of the both parties. Nevertheless, especially this cannot be for the commercial electronic transaction, they are presented on the basics of take-it or leave-it (Alhusban, Ahmad, 2014).

Under the JCL, if consumers purchase faulty goods and products on the "option of defect" then consumers have authority and right to return the item and receive their refund (Civil Law of Jordan. s 513). Hence, this situation is not much clear for the consumers if they have been misrepresented or misled in making the purchases, specifically, in the e-environment. Eenvironment where the consumers are necessary to present the evidence of loss which is also called loss evidence.

\section{WEAKNESSES IN JCL IN PROTECTING CONSUMERS FROM MISLEADING ADVERTISEMENT.}

Having referred to the general rules in the Jordan Civil Law, it is noticed that these provisions are insufficient and deficient to provide required protection from misleading commercials. Attempting to explore the degree of protection from misleading advertisements provided in the general rules of the Civil Law, it is noticed that there is a sort of deficiency in total provisions. For example, despite the possibility of recognition in considering laying or concealment, whenever its conditions are met, as a sufficient ground to prove deception, it cannot be said that the case of deception grants a consumer a comprehensive protection from damages of the misleading or deceptive commercials. Many difficulties may result from nature of application of the case from practical point of view, for example, proving deception raises several difficulties; normal consumers may be unable to prove the deception exercised by the producer, especially when it relates to technical details in connection with products or services (Wahdan, Reda Metwali, 2008).

Further, under the provisions of the Jordan Civil Law, burden of proof to prove that deception has caused criminal fraud is the responsibility of a consumer. A consumer who is victim of the lies contained in a misleading advertisement cannot terminate the contract unless it is not proven that the deception has caused a fraud; Article (145) of the Civil Law provides that " if either party deludes the other party and the latter discovers that the contract has been made upon fraud, then the latter may terminate the contract" (Jordan Civil Law.s 145).

As for penalty, when a consumer files a case of deception, he/she will face several difficulties and incur a lot of efforts and expenses, in addition to the procedural obstacles that a consumer may face against the professional advertiser. Further, the desired result sought by termination the contract is not quarantined, rather is not sufficient to remedy the damage to a consumer due to the misleading advertisement, as well as that termination of the contract does not match with 
the real desire of a consumer, where his intention has been to fulfill his/her needs (Zaqard, Ahmad, 2001).

As a result, reliance on the case of deception along with its conditions that must be met, and the negative penalty by termination of the contract, that is the right of a consumer if he wins the case, are not sufficient to provide real protection from the misleading commercials. As for the case of in-kind execution, a consumer often faces difficulties of proof and the long period of proceedings, where a consumer is responsible for proving commitment of the advertiser and his/her failure to perform the obligations.

As for components of the goods or services, subject of deception, the Civil Law requires that the deception should be the motive to contracting, i.e. to be consternated on the fundamental specifications of the goods or services, and whether it is accepted as to self-components of the goods, subject of the advertising, like its existence, nature, origin, features and components, where the situation is different as to the external components like production methods, contracting conditions, or the predicted results. Accordingly, the case of deception does not deal with components of the second group, and it therefore does not extend to include such components. Hence, consumer protection according to the case of deception is not comprehensive (Wahdan, Reda Metwali, 2008).

Furthermore, there are a numeral of considerations that discourage consumers from the follow-up of civil proceedings, for example, a general feature of civil law is that consumers have right to take initiative in originating and commencing the proceedings and demonstrate that run to the contravention of the rights (Almuaini, Abdelrahman H, 2009).

Furthermore, there are other reasons why consumers do not litigate: there may be absence and lack of motivation to take the matters further; the cost may appear too higher; the remoteness and formality of the courts may appear too daunting; and the amount that the consumer stands to recover, if he succeeds, may not make litigation worthwhile (AlGhafri, Abdulla, 2013). The main beneficiary of the positive role of the advisory bodies (voluntary or governmental) prior to the commencement of any legal action is the consumer, as the consumer will be able to make an informed decision which helps him to pursue legal action against rogue and unscrupulous traders more confidently and successfully (Ibid).

Furthermore, the Jordanian legislature is inadequate to implement an effective and efficient information disclosure as it is not sufficiently developed to ensure that consumers are able to make informed decisions. This weakness is a result; Firstly, the reliance upon the defects of consent theories in Articles 135-156 of the Jordan Civil Law, particularly fraud and mistake, does not seek to redress the imbalance of knowledge among contracting parties in order to ensure that the consumer is able to make informed decisions; rather, they seek to redress the consent if it was mistake or deceived. In addition, the Jordanian Civil Law does not explain whether the lying is considered as deceiving or not. So far, and there is no decision at the Jordanian courts in this issue.

Secondly, the general principle in Article 466 is uncertain as it merely requires that a business make the item sold known to the buyer. It is true that Article 161 (1) provides that the subject matter of the contract must be known; this requires the seller to provide the essential characteristics of the item sold if it was not presented at the time of sale. However, the JCL does not define the information that falls under the concept of 'the essential characteristics of 
the goods or services' and this may therefore lead to another uncertainty with regard to the information disclosure regime.

The weakness of consumer protection was due to the existence of some general provisions in civil law which are not clear in legitimizing the unfair trading practices such as cartels and monopolies, and thus lead to insufficient consumer protection.

\section{JORDANIAN CONSUMER PROTECTION DRAFT LAW 2013}

The Draft Law 2013 of Consumer Protection (DLCP) submitted to the Parliament in 2013 but has not been confirmed or gazetted yet. The Draft Law 2013 aims to protect the consumer in three features: (1) Government and institutions of civil society are monitoring of goods which ensures they meet the standard; (2) legislative aspect, which are revising all the consumers existing laws; and (3) awareness aspect which is related to the increase in consumer's awareness regarding their duties and rights (Jordan Times, 2013). In reviewing provisions of the draft law, which is considered the first step towards the future consumer protection law in Jordan, the preamble of the draft law introduces the essential components contained in the draft law, including consumer protection from misleading advertisement. Regarding to misleading advertisements issue the Draft law 2013 does not cover all aspects of misleading advertisements.

In exploring concept of "misleading advertisement", it is noticed that the DLCP does not define the meaning of "misleading advertisement", rather it just mentions that "the advertisement is considered misleading when it drives a consumer to make error".

Para (1) of Article (8) of the DLCP provides that "publication of any advertisement misleading a consumer or driving him/her to make error on the goods or services shall be prohibited". (Draft Law 2013.s8) Hence, the legislator places a prohibition of any advertisement that would mislead a consumer or drive him/her to make a wrong decision. This provision is, when ratified, will be the first of its kind in Jordan that deals with protecting consumer from the misleading advertisement.

It is noticed that the new provision contained in the DLCP places a general obligation on the advertiser to be prevented from publishing any advertisements that mislead a consumer and drive him/her to enter into contract without satisfaction. A consumer is the victim of false commercial, where a consumer can directly refer to the advertiser without the need for any contractual relation with the advertiser. Thus, the new provision provides a greater and more comprehensive protection than those provided by the general rules to a consumer (Khasawneh and Hattab, 2012).

According to Article (2) of the DLCP, an advertiser means "The provider who announces or promotes, or causes third party to do so, the goods or services by itself or by using any other advertising means" (Draft Law 2013.s 2). It is noticed that the legislator expands the concept of the advertiser to include any person carrying out advertising "or causes a third party" to include the producer, direct seller or even the service provider. The legislator also expands to place protection not only on the goods but also on the services.

Article (8) of the Draft Law provides that "publication of any advertisement misleading a consumer or driving him/her to make error on the goods or services shall be prohibited. The advertisement shall be considered misleading if it contains untrue, incorrect or incomplete data or information as to the following: 
1. The goods' nature, quality, composition, fundamental qualities, components and quantity.

2. Goods' origin, weight, size, manufacture method, expiry date, use conditions, or use prohibitions.

3. Service's type, place of delivery, delivery prohibitions, or fundamental qualities,

4. Contract's conditions, total price, and payment method,

5. Obligations of the advertiser,

6. Identity and qualifications of the service provider if considered in the contract"( Draft Law 2013.s 8).

\section{OMISSION OR SILENCE OF THE ADVERTISER}

A question raises whether omission or silence of the advertiser as to mentioning some data in the advertisement is considered misleading; the Draft Law does not address this issue, rather it just examines the general concept of " misleading", where it is envisaged that misleading may take place through omission by the advertiser of some data about the goods or the services which lead to making errors by a consumer. For example, a cell-phone vendor does not state that some displayed cell-phones are second-hand, and that an advertiser does not mention a certain service that such service shall be binding for a certain period under the contract (Khasawneh and Hattab, 2012).

Hence, definition of "misleading advertisement" shall be reviewed by adding concept of " misleading" through omission or silence in order to provide a consumer with a greater projection from the misleading advertisements. Therefore, legislation should deliberate both favourable and unfavourable information duties for the accomplishment of strong consumer protection and assist consumer in making more informed and better decision. The favourable information duties can be accomplished by demanding a business to arrange a detailed outline of information which should be in comprehensive and clear form. Furthermore, this list should detail the availability, delivery and benefit of each goods. However, the unfavourable information duties are reflected by the information that is vague, absent, ambiguous and misrepresentative (Stuyck, Jules, 2000).

As per general rule for the requirements of information, when focusing on the necessary and basic information which a consumer should identify, legislation emphases mainly on convenience, price and quality. The contemporary law of contract does identify other information that should be available at a specific point in a specific contact like pre-contractual information (Alhusban, Ahmad, 2014). Moreover, lack of consumer protection law reduces the JCL that is a base of legislation which includes the information requested on the Internet. Though, the dependency on the general rule of the JCL about release, considering as the main consumer protection criteria, advances specific concern due to its inadequacy. The consumer is specifically focused on the prices of the goods that can be measured as a fundamental point in the thinking of customer when deciding on a specific transaction.

Overall, it is derived from the idea of information release and for clarity in consumer protection that price is the significant information in the perspective of product. Sometimes, absence of price information is unfavourable in the purchase decision making process by consumer. Thus, legislature interference is essential to certify that such information is unambiguously and clearly specified. So, to certify that customers are not misinformed, the information must be 
fully described even if the price is comprehensive of delivery costs and tax or it comprises of other charge, also the time duration for which any deal is valid (Alhusban, Ahmad, 2014).

Moreover, the DLCP 2013 has introduced an important phase towards information duties. This can be confirmed from Article 3 (a) 2-3 and 8 (Draft Law 2013.s 3/A2-3 and s 8) which stated the right of consumer to acquire full and comprehensive information regarding a purchased product or services; the right to attain comprehensive information about a consumer's duties and seller's rights prior to the end of the contract; also, the right to attain complete information about the existence of the seller. Nonetheless to these rules and regulation, there are constitutional uncertainties regarding to three concerns.

Initially, the precondition of information in the draft law don't identify as to apply a duty on merchants to offer the above cited information; relatively, it is in favor of costumer to retrieve information which consequently put obligation on customer to ask for inquiry. This identifies that contractual and pre-contractual information conditions as per mentioned in draft law are considering to be an incentive to deliver information other than being directed to convey them is compulsory in nature.

Furthermore, the big intention of the draft law is introducing a system for consumer protection that has information transparency and legal certainty (Karky, Hetham Hani Abu, 2010). For offering a strong consumer protection with information duties, legislature must have to put an information obligation on advertisers to reveal seller's duties and consumer's rights rather than the additional method around, or slightly open information about the duties and rights of both consumer and seller.

Lastly, a same issue to the JCL concerning to the absence of clarity turn out in an association to the draft law because it is not describing or expounding the definition of whole information and what criteria exists (Alhusban, Ahmad, 2014).

The DLCP 2013 also reveals that consumer has fully right to acquire correct and complete information explained in a clear way about the procured product or services. Likewise, consumer has an authority to acquire full information related to the consumer's commitments and supplier's rights before making the final decision for purchase. Additionally, consumer may acquire correct and complete information related to the identity and address of supplier (Draft Law 2013.s 2/2-3 and 5).

Thus, the foremost question that comes related to the requirement of information under the concluding form of the draft law is rather to give the above-mentioned information is a compulsory obligation on the measure of the supplier side or whether information is a matter to the consumer's appeal. Moreover, the Draft Law gives a supportive response to this inquiry as $\mathrm{S} 8$ from the similar Article rejected a supplier from carrying out an action or abstaining from performing an act that moves to an interruption of any of a consumer's rights, containing those cited in the draft law.

Anyhow, the statement stated by the legislature 'the consumer has the right to acquire information' provides an ambiguous sense. Thus, it is needed to introduce a direct, clear and straight terminology by the legislature which will further eliminate any ambiguity related to seller's disclosure requirements (the foremost way of consumer protection) (Howells, Geraint, and Thomas Wilhelmsson, 2003). And form the duties a compulsory obligation in consumer agreements. This will assist consumer in making informed decision. These types of terminology must present the mandatory view of the obligation such as "the following 
information must be provide" instead of "the consumer has the right to get information" (Alhusban, Ahmad, 2014).

\section{RIGHT TO REFUND OR REPLACEMENT}

Remedies to give to the consumer the right to refund money or replacement the goods or services from the provider or seller because misleading advertisement is mentioned in Article 6 of the draft law. The article 6 of the DLCP shows the rights of consumer, that consumers has right of product return if the product was faulty and defective or the transaction was determined by the route of defective contract and on his or another request be refunding the paid price.

According to this section the Draft law followed the general principles under the JCL (Khasawneh and Hattab, 2012). The reliance upon the defects of consent theories in Articles 135-156 of the JCL, particularly fraud and mistake does not pursue to redress the inequality of knowledge among contracting parties in order to certify that the consumer is able to make knowledgeable decisions; rather, they seek to redress the agreement if it was mistaken or deceived. Consequently, the JCL does not offer pre-emptive intervention in terms of imposing specific pre-contractual and contractual information duties (Alhusban, Ahmad, 2014).

\section{CONCLUSION}

In Jordan, provisions are generally available in relation to mislead or deceptive in commercial advertising, and they must be modified to fit the case of commercial. These provisions are not in a way sufficient to protect the consumer in general, and particularly not enough to protect the consumer protection of misleading commercial advertisements.

Where the civil law in Jordan, is the main law for the all private laws in Jordan and is thus considered to be the applicable law in the absence of any rules. Such as the absence of consumer protection law. It is worth mentioning that the lack of definition consumer has led to a lack of rules governing consumer issues in Jordan. Hence, consumer protection according the misleading advertisement in the Civil Law of Jordan is not comprehensive. This situation has a negative impact on the feelings and perception of consumers toward the protection provided by law.

The Draft Law 2013 is not sufficient enough to protect the consumer from any misleading advertisement. In other words, the Draft law 2013 does not cover all aspects of misleading advertisements.

\section{References}

Abd El-Razzak El Sanhuri, Sources of Justice in Islamic Jurisprudence, 1st, Cairo, Dar A-Hana, (1960) 57 (in Arabic). Abdelaziz Lasasmeh." Civil Liability for Injurious Acts: Base and Conditions" , "Dar Althaqafah", Amman, (2006).

AlGhafri, Abdulla. "The inadequacy of consumer protection in the UAE: the need for reform." PhD diss., (2013).

Alhusban, Ahmad. "The importance of consumer protection for the development of electronic commerce: the need for reform in Jordan." PhD diss., University of Portsmouth, 2014.

Almuaini, Abdelrahman H. "The enforcement of copyright law in the United Arab Emirates." PhD diss., University of Aberdeen", (2009).

Alsarhan, A.” Jordan Civil Code: Sources of Obligations", “1st, DarAlthaqafah, Amman”, (2005), (In Arabic).

Howells, Geraint, and Thomas Wilhelmsson."EC Consumer Law-Has it Come of Age?." European Law Review 4 (2003): 370-388.

Jordan Times, "Cabinet endorses draft consumer protection law", [database online], retrieved from Jordan Times website, 2013. http://vista.sahafi.jo/art.php?id=9b95101f7b5319772a8bdb91849c67cd39316583. )Accessed in February 2016). 
Karky, Hetham Hani Abu. "Competition Policy and Consumer Protection Policy in Jordan." Penn St. Int'l L. Rev. 29 (2010): 335.

Khasawneh, Maha Youssef, and Hattab, Rasha Mohammed Tayseer. "Civil protection for the consumer of commercial advertising is misleading, according to the provisions of the Jordanian civil law and consumer protection Draft 2006." University of Sharjah Journal of Shari'a and Law Sciences 9, no. 1 (2012): 163-186.

Naji, Mula, "Methods of misleading and deception in commercials and addressing by Jordanian legislation, Analytical study", "administrative sciences studies", vol.1 (2000).

Sarhan and Khater ' explanation of the Jordan Civil Law, source of personal rights", "Dar Thakafa for publication and distribution",( 2005).

Sarhan and Nouri, "explanation of the Civil Law", "Dar Dar Al Thaqafa for Publishing and Distribution" Amman-Jordan. (2009).(In Arabic).

Stuyck, Jules. "European consumer law after the Treaty of Amsterdam: Consumer policy in or beyond the internal market?." "Common Market Law Review" 37, no. 2 (2000): 367-400.

Wahdan, Reda Metwali, " Advertising deception and its effect in fraud criterion", "Dar Feker and Qanoun", (2008).

Zaqard, Ahmad, " toward a general theory on contract drafting, a comparative study on the binding power in the contracting documents", "Rights Jouranal", issue 3, vol. 25, (2001). 